\title{
3 Experiencing the dead in ancient Egyptian healing texts
}

\author{
Rune Nyord
}

\section{Introduction}

Health problems ascribed to the agency of dead human beings in ancient Egyptian healing texts offer a number of interesting perspectives on cultural classifications of illness and local epistemologies. On the one hand, the problems are rarely described in enough detail to be of much use in discussions of universal versus 'local biologies' (sensu Lock 2001). But, on the other hand, they offer a prime example of the ways in which illness is embedded within wider conceptual, experiential and social surroundings. This in turn stresses the need for approaches that allow us to sidestep intuitive dualistic notions of illness in order to come to a better understanding of ancient experience (cf. Nyord 2017).

A number of different problems are ascribed in Egyptian medicine to a group of beings known simply as 'the dead', often specified further as 'a male or female dead' (Westendorf 1999: 360-94; Kousoulis 2007). It is tempting to see such connections as a purely theoretical construct whereby illnesses are explained by reference to the 'dead' as an aetiological principle. In this chapter, I will try to broaden this understanding to include considerations of the ways in which such conceptual aspects interact with embodied experience in the Lebenswelt ('lifeworld') of the ancient Egyptians.

\section{The 'dead' in Egyptian medical texts}

The overall picture one gets from the extant medical texts from ancient Egypt is that Egyptian healing practices mostly proceeded from what Foster (1976: 775) has famously called a naturalistic system, where

disease is thought to stem, not from the machinations of an angry being, but rather from such natural forces or conditions as cold, heat, winds, dampness, and, above all, by an upset in the balance of the basic body elements.

Thus, illnesses are often said to be caused by a variety of impersonal substances moving about or accumulating in the body or its parts. ${ }^{1}$ However, this picture is nuanced considerably by the occurrence of a fairly wide range of illnesses 
ascribed to the influence of gods or spirits (Foster's personalistic system), meaning that on closer scrutiny it becomes quite difficult to peg Egyptian thoughts about healing easily into one or the other of Foster's categories. ${ }^{2}$

From the famous general importance of the mortuary cult in ancient Egypt, it is not surprising that harmful spirits of the dead also play a prominent role in disease aetiologies. As will be seen later, these harmful 'dead' are to a large extent precisely those who fall outside the structure of the ancestor cult, although many details in this classificatory system remain less clear than modern scholars would like.

Terminologically, at least, the 'dead' form a relatively distinct category in the ancient Egyptian cosmos, although its boundaries and overlap with other categories shift noticeably depending on the context. Thus, one often finds an overall quadripartite scheme where 'humans' are classified along with 'gods, spirits and dead' to capture the main agents in the Egyptian cosmos. ${ }^{3}$ However, it is also clear that such lists are often given rather for the ritual efficacy inherent in capturing the maximum range of potential causes than as a disinterested practice of classification for its own sake, and correspondingly such lists of beings can be more or less elaborate and are often adapted to their particular context. Thus, in a spell where the attacker is conceptualised specifically in reptilian form, we find the characterisation 'a book for freeing a house from $<$ any $>$ male or female dead and any male or female serpent'. ${ }^{4}$ In other cases, we get sometimes quite lengthy lists of categories that seem to be at least partly overlapping, e.g. "no god or goddess, no male spirit or female spirit, no male or female dead, no male or female adversary shall have power!' 5 This indicates that at least in some cases, the underlying cause of the problems was understood on a very general level, with little interest in narrowing it down beyond what was necessary to deal with it in practical and ritual terms.

This relative fluidity raises some important questions of interest to the problems of illness classification and local biologies occupying us here. What does it mean for an Egyptian to ascribe a particular illness to the activities of a dead person, what criteria underlie this identification as opposed to different potential causes and how does the causal model inherent in our notion of aetiology square with the fluid nature of the Egyptian category of 'the dead'?

To begin with the latter question, Pascal Boyer (1990) has called attention to the way in which traditional concepts are often not structured around a formal definition or explicit model, but are instead acquired as a sort of invariance across different experiences presented as involving the concept in question. Boyer's (1990: 36) example is that of the mana-like concept of evur among the Fang people of Cameroon:

In short, one becomes an expert in evur by going through a series of personal experiences, notably a series of direct presentations of the world in which evur is visible. Being able to make definite statements about evur and having experienced such direct presentations of the ghosts' world are two qualities that seem necessarily connected. Indeed, the Fang conceive expert discourse 
as a consequence of such experiences. It is because someone has been in such situations that he or she makes certain statements about evur.

[...]

The expert does not acquire another, more refined 'definition' or 'characterisation' of evur; he or she acquires a repertoire of salient memories, which concern singular situations, not abstract principles.

I would argue that the Egyptian notion of the 'dead' can be usefully understood along similar lines. Rather than seeing the occurrence of the 'dead' in healing texts as fragmentary indications of an underlying formal theory about the 'dead' and what they can and cannot do, it seems likely that most, perhaps all, Egyptians will have related to the 'dead' on a case-by-case basis, and that the concept of the 'dead' will have been formed by the sum of such experiences.

Under this perspective one of the most important questions becomes how the 'dead', their attacks and the defence against them were experienced. The Egyptian healing texts do not deal with individual cases in a way directly amenable to this perspective, but by combining the information in the texts and posing questions directly dealing with the experiential aspects of the underlying situations, it becomes possible to provide some plausible background.

As with many other aetiological principles in Egyptian healing texts, the 'dead' occur mainly as part of a standard phraseology describing the solution of a problem. ${ }^{6}$ The first part consists of a verb denoting the act of healing, followed by a noun for the concrete manifestation of the problem and a genitive designating the ultimate cause, e.g. 'removing [HEALING] the influence [MANIFESTATION] of a male or female dead [CAUSE]'. Terse as they are, such expressions contain in themselves the basis for a number of inferences about the conceptualisation of the phenomenon in question.

First, we may observe that the treatment of influences of the 'dead' is almost always expressed with the verb $d r$, usually glossed as 'remove' or 'drive out', and basically denoting the forced movement of an entity out of a bounded area (von Deines and Westendorf 1962: 981-7). While this does provide us with a useful model for understanding the 'dead' as intruders entering the human body from outside and hence needing to be removed, it should also be noted that this model is extremely widespread in the Egyptian conceptualisation of illnesses more generally as foreign entities intruding into the body (cf. Westendorf 1999: 483-4). It is worth noting also that this idea is also found expressed in other ways than through the specific mention of the verb $d r$, e.g. as 'a male or female dead who has entered his belly'?

For a more detailed understanding of the role of the 'dead', we thus need to turn to the various manifestations envisaged by the medical texts (see Table 3.1). The two most frequent manifestations are designated by the Egyptian terms ${ }^{c 3 c}$ and $s t^{-}{ }^{c}$, respectively. Not only are they the most frequent, but they can also be seen as the prototypes of two overall modes of manifestation under which the more rarely attested concepts can be subsumed as well. We will return to this question of the two main modes of manifestation, but first it is instructive to take a closer look 
at the lexicography of the two main terms in order to understand the underlying conceptual patterns.

The term ${ }^{C 3 C}$ is derived from a root meaning basically 'flowing out' or 'pouring forth', used quite often of ejaculation (which no doubt provides the main prototype for the description of the activities of the dead), ${ }^{8}$ but also more rarely of the shedding of other body fluids such as spittle, ${ }^{9}$ or even of the baby in giving birth (Nyord 2009: 473-4). In the domain of landscape features, a noun from the root designates 'wellsprings' or the like forming an abundant source of fresh water. ${ }^{10}$

In other words, the influence of the 'dead' is conceptualised here as a special type of fluid pouring forth from dead or divine entities and injected into the body of the patient (Westendorf 1970, 1999: 361-6). These fluids work from the inside, and the illness is either not localised more specifically at all, or only in broad terms such as the 'torso'.

The manner of treatment confirms this picture, as it consists of methods intended to work from the inside out. This is true most obviously of various recipes to be ingested - often explicitly before going to bed, a point to which we will return later. But it is also likely that the other main method for treating ${ }^{c} \mathcal{C}^{c}$, censing, has a similar rationale in aiming to cleanse the 'tubes' or 'conduits' connecting the different body parts and hence also responsible for distributing harmful intrusive substances. ${ }^{11}$

A good example for elucidating the underlying conceptual structure can be found in a prescription forming part of a series for 'driving out the ${ }^{c} c^{c}$-fluid of a god or dead from the torso of a man or woman' 12 from the compendium known in modern times as Papyrus Hearst, dated to around 1550 BCE. The prescription itself is rather simple ('An $3 b \underline{d} w$-fish with the mouth filled with incense, cooked and eaten before going to sleep' $)^{13}$ and conforms to the general pattern just mentioned of remedies to be drunk or eaten before going to bed in order to expel the harmful substances. The spell to be recited in this connection provides further details helpful in understanding how the remedy works:

What is said concerning it [i.e. the fish] as heka: ${ }^{14}$

O male or female dead, hidden one and concealed one, who is in this flesh of mine, in these body parts of mine! Remove yourself from this flesh of mine, from these body parts of mine! Look, I have brought excrement to eat against you. Hidden one, leave! Concealed one, retreat! ${ }^{15}$

The underlying logic in this spell is instructive and bears a few remarks. The remedy consists conceptually of a set of nested containers: incense is placed inside the fish, which in turn ends up inside the patient through ingestion. The identification of the sacred $3 b d w$-fish in terms of modern species is uncertain, ${ }^{16}$ but in Egyptian thought it has strong connections with the sun god Re, whom it helps by accompanying the solar barque, or in some cases the fish is even regarded as an incarnation of the god. ${ }^{17}$ Eating the fish was correspondingly forbidden in certain ritual connections, though it is also in rare cases attested as being distributed as rations, and as shown by the example under discussion, it was also used for 
healing remedies. ${ }^{18}$ Incense is called in Egyptian $s \underline{t} \underline{t} r$, literally 'deifier', and its overarching cultic usage is that of preparing a location for the presence of a god or ancestor. ${ }^{19}$ This understanding of incense serves to reinforce or activate the divine association of the fish, so that what is eaten is essentially a godly substance serving to divinise the patient from the inside out. ${ }^{20}$

Against this background, the reference to eating excrement is slightly mysterious at first sight, but it can be understood by referring to the underlying model connected to the Egyptian concept $b w t$, often rendered as 'taboo' or 'abomination'. ${ }^{21}$ The main idea needed to understand the reference is that various beings have different 'abominations' depending on their place within the cosmos, as an expression of fundamental ontological compatibilities and incompatibilities. ${ }^{22}$ Thus, a mortuary spell indicates that the deceased cannot be eaten by a predatory being, because he has the $b w t$ of that being inside his belly. ${ }^{23}$ The prototypical 'abomination' in Egyptian thought is that of eating excrement, which would essentially reverse the natural order of the digestive process. ${ }^{24}$ When this idea is combined with that of the individual nature of specific 'abominations', one gets a situation somewhat reminiscent of the 'perspectivism' explored in social anthropology by Eduardo Viveiros de Castro and others. ${ }^{25}$ In this manner, a taboo substance is always regarded and treated as excrement by the being to whom the taboo relates. In other words, the reference to excrement here means that the contents of the belly of the patient are incompatible with his serving as prey for the 'dead' for reasons of $b w t$. Thus, as the 'dead' is presented as already being inside the body of the patient, it will now have to leave (Figure 3.1). ${ }^{26}$

The other main manifestation of the 'dead' is expressed by the compound $s t^{-}{ }^{c}$, an abstract expression referring generally to behaviour or situations characteristic of a particular individual. Thus, the $s t^{-}{ }^{c}$ of the god Osiris is the salient mythological situation where he is dead and mourned by his sisters Isis and Nephthys, ${ }^{27}$ while officials refer to their excellent $s t^{c}$ as the cause of the favours bestowed upon them by their superiors. ${ }^{28}$ In a manner highly characteristic of Egyptian

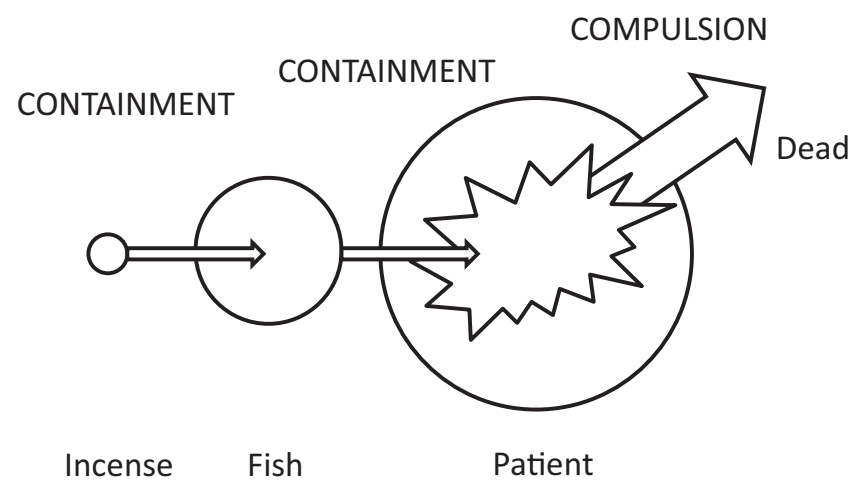

Figure 3.1 Conceptual structure of $\mathrm{H} 85$ 
patterns of conceptualisation, the word thus spans what we would tend to regard as two different meanings: on the one hand, the tendency or potential of a particular individual, and on the other hand, the way this tendency is actualised as behaviour, which in turn allows one to recognise the underlying tendency.

In healing texts, the word is used as a designation of the 'manifestation' or 'influence' of a particular being, usually a god or 'dead' (Westendorf 1999: 3669 ), and due to the basic meaning of the term, it is likely that even in the rarer cases where it occurs alone, it is to be understood elliptically as the manifestation of some kind of hostile being.

At first sight, this makes it somewhat more difficult to narrow down the conceptualisation of $s t^{-}{ }^{c}$ than was the case with ${ }^{c} 3$. However, from the root meaning, we would expect the word to designate an immediately observable phenomenon, and indeed, unlike ${ }^{c}{ }^{c}$, the $s t^{-}{ }^{c}$ is often understood to be localised in individual body parts. An elaborate example comes from the very first spell of the lengthy Papyrus Ebers, also dating to around $1550 \mathrm{BCE}$. The spell is a general one for 'applying a remedy to any body part of a man', ${ }^{29}$ and within the recitation it makes reference to

spells for driving out the influence (st- ${ }^{C}$ ) of a god or goddess, male or female dead, etc. $(\text { hmt-r })^{30}$ which is in this head of mine, in this neck of mine, in this shoulder of mine, in this flesh of mine, in these body parts of mine. ${ }^{31}$

This list indicates that while there are few limits to the parts of the body that could potentially be attacked by a $s t^{-}{ }^{c}$, more importantly, the attack is understood to be limited to a particular body part, unlike the case with the ${ }^{c}{ }^{c}$-fluid flowing freely inside the body. This picture is corroborated when looking at the means of treatment, which also predominantly consist of localised methods such as bandaging. ${ }^{32}$

A few remedies show that the effects of a $s t^{-}{ }^{c}$ could be understood in highly specific ways depending on the body part affected. Thus, another prescription from Papyrus Ebers is intended for 'driving out whitening from the eyes'; 33 within the accompanying recitation, the problem is mythologised as 'the influence of a male or female dead' which is to be driven out by the crew of the solar barque, as the eye problem is conceptualised in terms of the frequent cosmological motif of the victory of the sun god over his enemies seeking to stop the voyage. ${ }^{34}$

A slightly different perspective is offered by another prescription from the same papyrus dealing with a 'congestion of water' in the eyes. ${ }^{35}$ Here, the recitation contains a lengthy list of what must be construed as possible underlying causes and/ or effects of the problem treated: 'the water, the fluid, the blood, the blur, the $b d y$ illness, the blindness, the bleariness, the influence of a god, a male or female dead, male or female pain-substance, all bad things which are in the eyes, etc.' ${ }^{36}$ This would seem to indicate that all of the entities listed might lead to similar problems, either because the observable symptoms are indistinguishable, or because the ritual is meant to be all-purpose and cover all of these related problems.

The idea that the $s t^{-}{ }^{-}$-influence is bound to a particular location is found also in the case of an incantation from a manuscript, now in the Louvre, of slightly newer date than Papyrus Ebers, meant to 'drive out the influence of a male or 
female dead, etc.'. Here, the instructions specify that it is to be 'recited over (the goddesses) Isis and Nephthys drawn on any sick parts of the man' ${ }^{37}$ As a final example of the localised nature of the $s t{ }^{-}{ }^{c}$-influence, a remedy for treating the breast may be mentioned. ${ }^{38}$ The first part of the remedy offers a historiola providing a mythological precedent: ${ }^{39}$

These are the breasts in which Isis suffered in Chemmis, when she gave birth to Shu and Tefnut. What she did for them was an enchantment of them consisting of $j 3 r$-grass, a $\underline{t} 3$-bulb of $s n b$-grass, a $b k 3 t$-part of reed and the fibres of its $j b t$, brought to drive out the influence $\left(s t^{-}{ }^{C}\right)$ of a male or female dead, etc.

As is often the case, the myth is not presented in what might be called a 'canonical' form, but rather one which is tailored in its use of mythological patterns to suit its ritual deployment. Thus, we find Isis in Chemmis giving birth, not as usual to her son Horus, but instead to the first gendered couple in one of the most important cosmogonic narratives, Shu and Tefnut, thereby establishing a conceptual blend between the birth of Horus and the first creation of the divine pantheon normally taking place a few generations earlier.

The different plant materials are made into an amulet by twining them together, and revealingly it is said to be "placed at the (area of) influence of the male or female dead', ${ }^{40}$ once again corroborating that the problem is an observable and localised one. The recitation addresses the attacker with the words 'do not make discharge, do not make chewing, do not make blood', ${ }^{41}$ thereby giving an indication of the type of problem involved here, presumably some type of chap or abscess in the breast of a lactating woman. ${ }^{42}$

\section{Conceptual and experiential patterns}

We are thus dealing with two rather different modes of potential attack from the 'dead'. One is made through the ${ }^{c 3}{ }^{c}$-substance exuded by the 'dead' and gods and injected into the body of human beings. There, it causes pain or other problems from within, which tend to be ascribed generally to the whole body or the central organs of the torso. Correspondingly, the treatment consists in introducing other substances into the body which can replace the harmful fluids of the 'dead'. The two main therapeutic approaches to this are the ingestion of certain efficacious substances and censing, which also has the likely purpose of replacing the harmful substances found in the conduits of the body. This mode thus has a focus on the integrity of the body as a container and on the orifices as conduits for exchanging or replacing its contents.

The second mode is exemplified by the $s t^{c}{ }^{c}$ influence, which is manifested on the surface of the body in a particular place. It is not said explicitly, but the implication seems to be that the 'dead' becomes manifest directly on the surface of the body without first entering it through an orifice. Correspondingly, the treatments consist of bandages, amulets or drawings applied to the affected place on the body.

The overall difference between these two modes can be characterised in terms of image schemata as understood by philosopher Mark Johnson, that is, as 
pre-conceptual structures arising from embodied experience. ${ }^{43}$ The internal mode of manifestation is characterised by the CONTAINMENT schema, namely the experience of the body as a vessel into and out of which various substances move, some good and pleasant, and others bad and unpleasant. ${ }^{44}$ In contrast, the external mode is structured by the SURFACE schema, where the salient part of the body is regarded as a plane which other objects and substances can stick to or cover in its interaction with the surroundings. ${ }^{45}$

The very few exceptions to the overall pattern described can also be explained from this perspective. These are found where the 'belly'/'torso' (Egyptian $\underline{h} t$ ) is concerned, likely because of the ambiguity of this term, which basically denotes the trunk of the body and is hence amenable to construal as both CONTAINER and SURFACE. ${ }^{46}$ Thus, we find a case of a $s^{-}{ }^{c}$ on the belly, which can be driven out by drinking a beer-based emetic, possibly because that is regarded as the best way to target the location in question. ${ }^{47}$ And, conversely, a single prescription is found where ${ }^{c 3 c}$ in the belly or heart ${ }^{48}$ can be removed by treating the surface of the body with an ointment. ${ }^{49}$

The modes of treatment can be elucidated in a little more detail when this experiential aspect is considered. Thus, the difference between a concern with substances moving through orifices on the one hand and with restoring the integrity of the skin through bandaging on the other is not just connected to a theoretical model of the human body, but also corresponds to some of the most fundamental and persistent embodied experiences.

The less-frequently attested types of manifestation of the dead listed in Table 3.1 fall relatively easily within the two main categories typified by the CONTAINER and SURFACE schemas. Thus, 'poison' ( $m t w)$ affects internal organs and is treated by censing, conforming to the pattern of the ${ }^{c{ }^{c}}$-substance. ${ }^{50}$ The

Table 3.1 Manifestations of the dead in ancient Egyptian medical texts

\begin{tabular}{|c|c|c|c|}
\hline Manifestation & Body parts affected & Treatment & References \\
\hline${ }^{c}{ }^{c}$-substance & Torso, body & $\begin{array}{l}\text { Ingestion before going } \\
\text { to bed } \\
\text { Censing }\end{array}$ & $\begin{array}{c}\mathrm{Eb} 99,225,229,231 \\
168 ; \mathrm{H} 83 ; \mathrm{B} \ln 58\end{array}$ \\
\hline Poison $(m t w)$ & Heart, interior & Censing & $\mathrm{B} \ln 58$ \\
\hline Congestion (shnt) & - & Ingestion & Bln 116 \\
\hline Influence $(s t-\mathcal{C})$ & $\begin{array}{l}\text { Body parts, body, } \\
\text { breast }\end{array}$ & $\begin{array}{l}\text { Bandage } \\
\text { Censing (once) } \\
\text { Amulet w/ knots (once) }\end{array}$ & $\begin{array}{l}\mathrm{Eb} 242,244-245,811 \\
\quad \mathrm{~B} \ln 66 ; \mathrm{H} 72-73\end{array}$ \\
\hline Shadow $(\check{s} w t)$ & Body & $\begin{array}{l}\text { Ointment } \\
\text { Spell }\end{array}$ & $\mathrm{B} \ln 89,101 ;$ H 214 \\
\hline Strike $\left(? t^{3} r\right)$ & - & Amulet & L 30 \\
\hline Attack (sqr) & Eyes & Put on eyes & Ostr. Cairo \\
\hline Breath & - & - & $\operatorname{Sm} 8$ \\
\hline Unspecified & Flesh, body parts & $\begin{array}{l}\text { Ingestion } \\
\text { Ointment }\end{array}$ & $\mathrm{H} 85 ;{ }^{1} \mathrm{~B} \ln 99$ \\
\hline
\end{tabular}

1 This prescription forms part of a series for 'driving out the ${ }^{c}{ }^{C}$-fluid of a god or dead from the torso of a man or woman', so although the prescription itself does not mention this specific manifestation, it can be grouped in the ${ }^{c}{ }^{C}$-category with good certainty. 
'congestion (shnt) of a male or female dead's1 is paralleled with other harmful body-internal substances and is treated by ingestion, revealing it to conform to the same conceptual pattern. Similarly, the manifestation $t 3 r$, meaning 'strike' or similar, can be seen from the spell to result in vaginal haemorrhage, and the remedy correspondingly aims at safeguarding this bodily orifice. ${ }^{52}$ Conversely, the $s q r$, 'attack', corresponds to the pattern of $s t^{-}{ }^{c}$ in being localised to a specific body part (in this case the eyes) and targeted by external treatment. ${ }^{53} \mathrm{~A}$ single notion, that of a 'shadow' ( $s w t$ ) of a god or 'male or female dead', seems to be of a more general nature and blends elements from the two main models by, on the one hand, affecting the patient globally, but on the other being viewed as external, as is indicated by the treatment with ointment ${ }^{54}$ and the main spatial conceptualisation of the patient being 'under' the shadow ${ }^{55}$ or, in a positive sense, being 'far away' from it. ${ }^{56}$ While it is too rarely attested to elucidate further, it seems the 'shadow' as illness phenomenon may be modelled on a third general embodied scenario having to do with the behaviour of visible shadows.

If we understand the conceptual model and embodied experience as two different levels, with the former dependent on structures borrowed from the latter, we can think of the curative ritual recitations and actions as either an additional, third level or as a way to bridge the gap between conception and experience. Indologist Ariel Glucklich (1994) has used the notion of resonance for this relation, where there is an isomorphic correspondence between the conceptual and phenomenological aspects of a ritual.

Thus, the treatment, whether we prefer to regard it in individual cases as ritual or medical, tends to 'resonate' with the salient conceptual model of the body. The example of eating the incense-infused $3 b \underline{d} w$-fish is instructive of the way in which the system of nested CONTAINERS internalised by the patient resonates with the conceptual model of the fluids of the 'dead' hidden inside the body of the patient and entering and exiting through the orifices. Similarly, the use of bandages and amulets placed on the sick body part and the corollary experience of reinforcing or emphasising the body's boundaries resonate with the SURFACE schema structuring the conceptual understanding of the illness as an attack directly on the boundary of the body.

\section{Protection from the 'dead'}

Apart from these specific curative measures, there is evidence also of taking more general prophylactic precautions against the 'dead'. Thus, one prescription in the Berlin Medical Papyrus describes an ointment for vanquishing enemies and driving out the 'dead', ${ }^{57}$ but the remark that the ointment makes it impossible for the 'dead' to enter the body shows that the use was intended as prophylactic. ${ }^{58}$ This prescription does not specify the type of manifestation envisaged, but the treatment by ointment, otherwise unusual in relation to the 'dead', certainly falls under the heading of an experiential emphasis on the surface of the skin, either in its own right or as a boundary zone for entering deeper into the body, thus making it potentially isomorphic with either of the main modes of manifestation discussed earlier. 
Prophylactic measures against the 'dead' can be taken on a larger scale as well. Thus, according to another prescription, an ointment is to be applied to the doors and windows of the house to keep out the 'dead', basically replicating the concern with bodily orifices on the larger scale of the building. ${ }^{59}$

A group of preserved amuletic papyri serve the same general purpose ${ }^{60} \mathrm{An}$ example is a rectangular piece of papyrus now in the Louvre which was inscribed with powerful images and a personalised protective spell and subsequently folded into an amulet to be worn around the neck. The spell takes on an aggressive tone, threatening potential attackers with various supernatural retributions: ${ }^{: 1}$

If this enemy comes - a male or female dead and all adversaries coming to fall upon Mutemheb son of Aset, by night or by day, at any time - then you shall be disturbed in your tomb, you shall be sought out violently(?), a snare shall be set in the sky for you, while Seth is against you on earth, and you shall be caused to sail downstream without letting you moor. I would destroy your tomb and break your sarcophagus.

The list of 'threats' (cf. Morschauser 1991; Nordh 1996) linked conceptually to the haunting is typical of protective incantations. Often they express upheavals of a cosmic nature, creating a link between the haunting and such catastrophes as central rituals for the major gods not being carried out, thereby bringing the entire cyclical world order in danger. ${ }^{62}$ In such cases, the notion of 'threats' may be something of a misnomer, as the litany of disasters is intended rather to effect the conceptual impossibility of the haunting than to deter the haunter by logical arguments. ${ }^{63}$ However, in the amulet cited here, the negative consequences take on a more personal tone, relating directly to the situation of the 'dead' in the Egyptian cosmos, thus making them seem more like actual threats - although the underlying ritual mechanism is probably much the same.

The threats of being disturbed in the tomb and sought violently are immediately understandable in relation to the intrinsic connection of any deceased with the tomb. ${ }^{64}$ The next threats relate to the ideal of free movement playing an important role in funerary texts, the 'snare' preventing the deceased from moving, with the inverse problem being found in the threat of not being able to moor. These obstacles would thus not only be undesirable to any deceased (cf. Zandee 1960: 125-33), but perhaps more importantly, would also in practice have prevented the 'dead' from continuing the haunting. In other words, while the text is remarkable in taking up the perspective of the 'dead' to a large extent, this may be less motivated by the wish to appeal to his or her self-interest, and once again more a question of establishing the logical impossibility of the continued haunting.

\section{The identity of the 'dead'}

So far, we have primarily focused on the specific interplay between the 'dead' and the living body, with a secondary role played by the healer able to control the presence of the 'dead'. This is very much the perspective taken by the Egyptian texts themselves and indeed conforms well to our notion of homeostasis as a matter of 


\section{Rune Nyord}

interplay between the organism and its environmental surroundings. However, to elucidate the experiential side of the phenomenon more fully, it is necessary to take into account the way in which the 'dead' as causers of illness are embedded into wider social and ritual structures. A key question in this regard is that of the exact identity of the 'dead', and how this identity may affect experience.

Logically speaking, the notion of a 'male or female dead' indicates that these entities were once living persons. It is a general Egyptological convention that the 'dead' are distinguished from the 'spirits' or $a k h u$ by the latter having been given a proper funeral and mortuary cult, allowing them to enter the category of ancestor spirits. ${ }^{65}$ The 'dead', in contrast, are generally anonymous threats that need to be averted, without having the social and ritual entanglements of the 'spirits'. There is no doubt that this view is largely correct, but it is also clear that it is somewhat selective in the choice of sources substantiating it and could be nuanced. As a first step towards this, Sylvie Donnat (2007) has argued that the 'dead' and the 'spirits' are not mutually exclusive categories but can instead fruitfully be regarded as the result of two different patterns of social and ritual interaction. This view is made plausible by the fact that such a ritual constitution where a 'liminal' being is given a particular shape and category through ritual interaction rather than possessing an essential identity a priori is highly characteristic of Egyptian religion more generally. ${ }^{66}$

We have few sources speaking directly to the question of what it is that makes someone who has died a member of the category of the 'dead' in this narrower sense, whence the largely negative hypothesis that this is the fate of persons that do not get the ritual treatment necessary to become an $a k h$. A rare suggestion of an answer to this question is found in a list of threatening beings to be averted in Papyrus Edwin Smith: ${ }^{67}$

Any male or female spirit, any male or female dead, the form of any animal, one whom the crocodile has seized or the snake has bitten, one doomed to the knife or who has passed away on his bed, the night-demons of the year's wake or contents.

In relation to the point just discussed, we may start by noting that both spirits and 'dead' occur side by side with each other in this list as being potentially threatening to living humans. But, more revealingly, we find a list of beings that have died in various specific ways, making them prone to the behaviour which the spell seeks to counter. The notion that those who have suffered a violent or premature death are particularly likely to stay among the living to haunt them is of course very frequent cross-culturally, ${ }^{68}$ and the mentions of falling prey to dangerous animals or being murdered with a knife conform well to this picture. The mention of passing away in one's bed seems to run counter to this picture, ${ }^{69}$ and we need a bit of background to understand that notion.

Dying in one's bed is likely to refer to either or both of two different possibilities: one being dying of illness ${ }^{70}$ and the other dying in one's sleep at night. Death from illness could easily fit into the pattern of violent or otherwise remarkable 
deaths in the preceding list, so it is especially the notion of dying in one's sleep that needs elucidation. As in other cultures, the 'dead' were regarded as being particularly active at night. Thus, curative remedies are often said to be applied before going to bed (Westendorf 1999: 366), ${ }^{71}$ and one spell against "night spirits' consists in passing an amulet over one's food and bed to keep the spirits at bay: ${ }^{72}$

A man should recite this spell over the front of a fresh flower, tied to a branch of $d s$-wood and bound with a strip of first-class linen, passed over the thing (to be protected). The disease will be driven off and the passing of nightspirits will be barred over anything to be eaten as well as over the bed.

The vulnerability of 'anything to be eaten' is understandable from the basic CONTAINER schema entailing that ingestion is one of the main ways in which good or bad substances enter the human body, while the vulnerability of the bed needs to be understood with reference to the place of the night and sleeping in Egyptian cosmology (cf. de Buck 1939; Szpakowska 2003: 15-40). The night in general is seen as the immersion of the world into a regenerative but also potentially dangerous state of partial chaos where the categories making up the created world become blurred. This makes the night particularly hazardous in the case of spirits drawn to crossing into the world of the living, of which the word 'night-spirits' in this spell is thus an apt general designation (cf. Szpakowska 2011).

The general picture is thus one of 'unusual' manners of death, especially those which can themselves be connected to activities of the 'dead', being particularly apt to result in hauntings. This is corroborated by a somewhat later, much more extensive list of modes of death characterising the 'dead' who haunt the living. This list of 'every death reckoned by name"73 comes from a 20th dynasty (approximately $1100 \mathrm{BCE}$ ) instruction for a fumigation ritual against the 'dead' and forms part of the accompanying recitation, which makes an effort to capture every possible scenario. Among the modes of death connected to haunting, we find again the attack of dangerous animals such as crocodiles, lions, snakes and scorpions, a wide range of illnesses and accidents, including interpersonal violence (e.g. 'being killed by a weapon', ${ }^{74}$ and 'by any blow, by any knife'), ${ }^{75}$ and a comprehensive list of body parts (e.g. 'from his head'), ${ }^{76}$ presumably to be understood as dying as a result of illness or injuries affecting the body part in question. ${ }^{77}$ In a similar way, another spell from a manuscript dated roughly to the late 19th or early 20th dynasty (around $1200 \mathrm{BCE}$ ) provides a list of possible places of origin of the 'dead' responsible for the haunting:

Male or female robber, enemy, whether buried or unburied, who are in any crypt, who are in any mound, who are in any abattoir, who are in any shroud, in any place or any hollow, anywhere you want, male or female dead, male or female enemy, male or female adversary, any male or female robber who could do anything bad or ill against him $!^{78}$ 
Such lists clearly apply conceptual, and occasionally speculative, knowledge of the mode of existence of the 'dead' in general to the experienced situation in order to capture the concrete case within a more encompassing picture of the ontology of the adversary responsible.

Thus, the texts for healing and protection are not generally concerned with the more specific identity of the 'dead' attackers, relying instead on lists and classifications meant to cover every possible scenario, which in turn leaves the impression of an anonymous group of dangerous, mostly depersonalised spirits. This view has been generally accepted in modern analyses, perhaps also because modern observers have been apt to regard the 'dead' as a mainly theoretical explanatory model in the absence of 'rational' explanations of particular phenomena. ${ }^{79}$ However, as we have seen, individual living persons could also be thought to join the category when they die under particular circumstances, and indeed there are other, more sporadic indications that the identity of the dead person was known and of some significance, providing an important social aspect to the phenomenon.

As an example of this, we may take a spell from the London Medical Papyrus from around $1350 \mathrm{BCE}$. The spell belongs to a group to avoid haemorrhage, more specifically, as indicated by the contents, miscarriage. ${ }^{80}$ The spell of interest here conceptualises the attack of the 'dead' in specifically sexual terms by contrasting the fertile procreative sexuality of the god Osiris with the sterile and destructive sexual activity of the god Seth. ${ }^{81}$

Thus, the fertile seed of Osiris is addressed directly and told to 'Go out against this the male or female dead, etc.', followed by the revealing instruction to the performer to supply in the recitation 'the name of the enemy, the name of his father, and the name of his mother' ${ }^{82}$ Similarly, as part of the ritual instruction, a loaf of bread used in the ritual is said to be 'made with the name of the enemy, [the name of] his father, and the name of his mother' ${ }^{83}$ In other words, the ritual could only be performed as instructed if one knew the exact identity and filiation of the 'dead' performing the haunting.

It is entirely possible that there may have been divinatory or other practices which have not been preserved allowing one to identify the particular dead person responsible for the haunting. ${ }^{84}$ In this case, many of the other remedies discussed so far may also have been performed with the knowledge of the identity of a specific deceased in mind, although the treatments do not explicitly require this knowledge. In the particular spell we are discussing here, the recitation does in fact give us an indication of how the identity of the 'dead' is known, as the goddess Mafdet, playing a central role in the mythologisation of the situation, is spoken to with the words 'O Mafdet, open your mouth against that enemy, the [male] or female dead, etc.! Do not make me see him again!' 85 We can surmise from other sources that the reference to 'seeing' the 'dead' here concerns the appearance in dreams, and the matter-of-fact way in which this is mentioned makes it likely that this would have been an ordinary way in which one would know that one was under the influence of a dead person. ${ }^{86}$ 
The implication of the filiation formula seems to be that the 'dead' responsible for the haunting would be known to the patient, which raises a number of social implications. In general, deceased humans retained a central role in ancient Egyptian society through the legal and social embeddedness of funerary rituals and the mortuary cult (Baines and Lacovara 2002; Donnat and Moreno Garcia 2014). From so-called letters to the dead, where living persons wrote to deceased ancestors to enlist their help or avert their anger, we know that ancestors were occasionally asked to protect against such attacks from hostile dead (Donnat Beauquier 2014). Thanks to their power and social entanglement with both the living and the dead, the ancestors would have been a natural place to turn for protection against hauntings. Thus, letters to the dead contain general phraseology very close to that of the spells for healing and protection discussed here, as when the ancestor is asked 'Please, may you grasp this male or female dead' ${ }^{87}$ or in more detail, 'Make then your judgment against the one who causes me pain, for I will be vindicated against the male or female dead who does this against my daughter' ${ }^{88}$ However, in other cases it is clear that the haunting 'dead' is not an anonymous force, but a deceased person well known to the deceased - in some cases, in fact, the ancestor him- or herself. ${ }^{89}$

An example of the way in which social ties and responsibilities continue beyond the grave and have relevance for the experience of haunting is found in a letter written presumably by a son to his dead father, in which he complains about 'this which your servant Seni does, (namely) causing yours truly to see him in a dream in one city [together with] you' ${ }^{90}$ While it is not said directly, the strong implication is that Seni is deceased, and that the writer of the letter had wronged him, probably even to the point of being complicit in his death. Not only does this score continue beyond the grave, but we can also observe how Seni's superior can still be approached to make his servant cease his hostilities, even after they are apparently both dead. It may further be noted that we once again find the dream apparition as the source of the knowledge that one is under attack by a dead person (cf. Nyord 2009: 456-7), although it is not spelled out in this case whether the letter writer suffers from illness as a result.

A full examination of the evidence for this social embedding of problems with the dead falls outside of the scope of this chapter, but the London spell and the letters to the dead serve as an important reminder that if we want to study the ways in which the presence of the 'dead' in living bodies was experienced in practice, we need to go well beyond the concerns of the individual body, even if that happens to be the main perspective taken in most of the sources attesting these experiences.

The notion in the London recipe cited earlier that the assault by the 'dead' is sexual in nature is quite explicit both in this text and a few others (cf. Westendorf 1970), and it may also underlie the larger group of texts referring to the ${ }^{c 3}{ }^{c}$-fluid of the 'dead', since as seen earlier this term denotes bodily emissions. The explicitly sexual conceptualisation of the assaults is found in particular with a group of recipes, to which the London text also belongs as mentioned, to protect pregnant women against miscarriage. ${ }^{91}$ 
The danger of a sexual assault by the 'dead' was present not only during pregnancy, but also at the delivery itself, ${ }^{92}$ as one of the earliest extant medical texts, from ca. $1800 \mathrm{BCE}$, preserves a 'ritual done for him (sc. the new-born) on the day of his birth' ${ }^{93}$ The accompanying incantation addresses a group of protective entities, asking them to strengthen the bodily boundaries 'so that this dead one does not have intercourse, impregnate or embrace by night, nor kiss by day'. ${ }^{94}$ The incantation makes clear that it is the mother who is the immediate target of these approaches, but as shown by the cited heading, it is the new-born child that is the ultimate beneficiary of the protective rite, and the ritual also includes a prognosis predicting whether the child lives or dies. Most likely, this is to be understood against the background of the spells for protecting pregnant women just discussed, so that the activity of the 'dead' against the mother may still be harmful during and just after delivery. Other spells are intended to be spoken by the mother to protect her child against the 'dead', but in this domain the activity of the 'dead' is generally conceptualised as being that of 'taking' the child, ${ }^{95}$ with the dead correspondingly being called a 'robber'. ${ }^{96}$

On the one hand, the notion of sexual assaults by the 'dead' which can in turn lead to abortion certainly belongs under the heading of the CONTAINER image schema as discussed earlier, and this understanding captures some central details of the Egyptian understanding of the phenomenon. On the other hand, it is also clear that such an analysis, if allowed to stand alone, would be a reductive approach at the risk of ignoring salient aspects of the doubtless horrifying experience of sexual assault by the 'dead', in some cases by someone whose identity is known to the victim, and the risk of miscarriage or stillbirth this entailed for the unborn child. The references to dreams, terse as they are, show us that we would err if we regarded the phenomenon examined here merely as an abstract aetiological model, even one based on embodied schemata. While the nature of the sources leaves us little chance of capturing the details that could help rectify this picture, this deficiency in our understanding is well worth bearing in mind. This is especially true given that, following Pascal Boyer as discussed earlier, the emic understanding of the phenomenon of haunting by the 'dead' may be constructed precisely on the basis of such salient, individual experiences, rather than through abstract reasoning about the capabilities of a particular category of beings in the cosmos.

\section{Conclusion}

The case study of the 'dead' in ancient Egypt shows the need, which could be met only partially here, to go beyond the specifically 'medical' writings to elucidate the phenomenon. The dead are so salient in ancient Egyptian daily life experience and practice that it is necessary to view their role as causers of illness as embedded within the wider social roles of deceased humans, as well as the different ways they can be classified and interacted with. While the role of the dead is thus part of a much larger discussion of social, religious and experiential issues, the more limited questions I have discussed in detail here can in themselves lead to important 
insights. The problems ascribed to the 'dead' are an area where the strictly medical details are mostly too scant to allow convincing correlations with modern disease terminology, which in turn means that a different methodology needs to be sought to go beyond the conventional idea that the Egyptians explained illnesses for which they did not know the real cause by reference to evil spirits.

In terms of the broader question of illness classification taken up in this volume, the case study of the 'dead' as causers of illness provides a detailed example of the ways in which direct experience of illnesses and their symptoms becomes entangled with conceptual and theoretical knowledge about the ontology of the 'dead', which can lead to problems for traditional approaches that tend to privilege the latter side of the coin.

By drawing on ideas from phenomenology and cognitive studies, it becomes possible to analyse conceptual structure and classification as well as the connections between illness and treatment, while largely sidestepping the question of the relation to universal biological phenomena. It is worth mentioning that this approach is useful not only for the kind of 'personalistic' aetiologies that have occupied us here, but also for more 'naturalistically' oriented models of the internal workings of the human body (cf. Nyord 2017). This provides a method by which it becomes potentially possible to bridge the gap between 'us' and 'them' by basing the discussion on fundamental notions such as image schemata and their deployment. Such schemata can, on the one hand, be assumed to be shared by both the ancient Egyptian and the modern observer by virtue of the shared bodies and cognitive systems, while on the other be capable of embedding within the wider social, experiential and conceptual structures that are crucial for a full understanding of ancient illnesses.

\section{Notes}

1 See the overview in Westendorf (1999: 328-60).

2 For further discussion see the introduction and Steinert's contribution in this volume.

3 E.g. Papyrus Edwin Smith 18, 18 (= Breasted 1930: pl. 18).

4 Papyrus Ramesseum IX, 2,1 (= Gardiner 1953: pl. 41).

5 Papyrus Leiden I 348, recto 9,5-6 (= Borghouts 1971: pl. 9).

6 For the formal structure of such texts more generally, see Dieleman (2011: 91-7); Nyord (forthcoming).

7 Papyrus Leiden I 348, verso 11,9 (= Borghouts 1971: pl. 15). Likewise, outside of the corpus of texts conventionally labelled 'medical' in Egyptology, we occasionally find more specific descriptions of the means of attack, e.g. pBM EA 9997, 4,7 (= Leitz 1999: pl. 4), 'the dead who has bitten him'.

8 I thank Ulrike Steinert for making me aware of the similar use of the Akkadian verb reĥे, 'inseminate, pour over', cf. Reiner and Roth (1999: 252-4).

9 E.g. 'Horus (speaks to) Osiris: 'His (sc. Seth's) spittle shall not be expectorated $\left({ }^{c} 3<c^{c}>\right)$ against you' (Dramatic Ramesseum Papyrus, scene 11, col. 33 = Sethe 1928: pl. $14=$ Geisen 2018: 93 and pl. 3).

10 'They shall let the King eat from the fields and drink from the wellsprings $\left.\left({ }^{C}\right)^{c} w\right)$ within the Field of Offerings' (Pyr. 1200a - c [518] = Sethe 1908-22: II, 170).

11 As argued by Bardinet (1995: 216-17).

12 Papyrus Hearst 6, 16-17 (H 83) (= Grapow 1958: 258). 
13 Papyrus Hearst 7, 4 (H 85) (= Grapow 1958: 267).

14 The Egyptian word $h k$ ' is conventionally translated by 'magic', perhaps justifiable in this particular case by its reference to an efficacious spell spoken to influence the situation at hand. For critique of the Egyptological use of the notion of 'magic', and especially the ways in which it has been used to blur the lines between etic and emic terminology, see Otto (2013); Nyord (2019).

15 Papyrus Hearst 7, 5-6 (H 85) (= Grapow 1958: 267). The translations of all cited passages from Egyptian texts are my own.

16 Gamer-Wallert (1970: 27-9).

17 See the references collected by Borghouts (1971: 210-12).

18 Borghouts (1971: 212-13).

19 See e.g. Manniche (2009) for an overview, cf. Germer (1986).

20 Cf. Nyord (2009: 367) for this combination of CONTAINMENT and COMPULSION in medical texts.

21 See fundamentally Frandsen (2001).

22 Frandsen ibid.

23 CT V, 267d [424] (= de Buck 1935-61: V, 267, cf. Nyord 2009: 74, n. 336).

24 Cf. in particular Topmann (2002).

25 E.g. Viveiros de Castro (1998: 469-88).

26 Cf. the similar, but much simpler, use of the Tilapia nilotica (Egyptian jnt), which shares many of the mythological associations of the $3 b \underline{d} w$-fish, to block a snake from coming out of a hole by placing the dried fish in front of it, in Papyrus Ebers 97,18 (Eb 842) (= Grapow 1958: 526, cf. Borghouts 1971: 213-14).

27 'Isis wails for you, Nephthys calls to you, and the Great Mooring Post removes obstructions for you, like (for) Osiris in his 'characteristic situation' (st- ${ }^{-}$') (Pyr. 872ac [461] = Sethe 1908-22: I, 487; sim Pyr. 884b [466] = Sethe 1908-22: I, 493).

28 E.g. 'I grew up at the feet of Her Majesty since my first youth, because she recognised that my 'characteristic behaviour' $\left(s t-{ }^{-}\right)$was excellent, and I cleaved to the path of the official' (Cairo CG 20543, A10-11 = Petrie 1900: pl. 15).

29 Papyrus Ebers 1,1 (Eb 1) (= Grapow 1958: 530).

30 I.e. an instruction for the ritualist to expand the list of entities during recitation as appropriate.

31 Papyrus Ebers 1, 3-5 (Eb 1) (= Papyrus Hearst 6, 7-8 (H 78) = Grapow 1958: 531).

32 A pattern also observed by Westendorf (1999: 366), but missed by Kousoulis (2007: 1050), who cites the exceptional use of an emetic to cure a case of $s t^{-}{ }^{c}$ in H 216 (= Grapow 1958: 536, cf. the discussion on p. 91 above of this and other rare exceptions) as a typical example of treating this manifestation.

33 Papyrus Ebers 58,6 (Eb 360) (= Grapow 1958: 84).

34 Papyrus Ebers 58,7-13 (Eb 360) (= Grapow 1958: 84).

35 Papyrus Ebers 60,16-17 (Eb 385) (= Grapow 1958: 75).

36 Papyrus Ebers 60,19-22 (Eb 385) (= Grapow 1958: 75-6).

37 Papyrus Louvre E 32847, rto x+24,1-3 (= Bardinet 2018: 336).

38 Papyrus Ebers 95,7-14 (Eb 811) (= Grapow 1958: 489-90); an additional copy is preserved in Papyrus Louvre E 32847 rto x+10,6-11 (= Bardinet 2018: 304).

39 Papyrus Ebers 95,7-10 (Eb 811) (= Grapow 1958: 489; cf. Papyrus Louvre E 32847 rto $\mathrm{x}+10,6-9=$ Bardinet 2018: 304).

40 Papyrus Ebers 95,11 (Eb 811) (= Grapow 1958: 489); this instruction is skipped in the Papyrus Louvre E 32847 copy (cf. Bardinet 2018: 88).

41 Papyrus Ebers 95,11-12 (Eb 811) (= Grapow 1958: 489-90; cf. Papyrus Louvre E 32847 rto $\mathrm{x}+10,9=$ Bardinet 2018: 304).

42 Cf. the discussion in Jean and Loyrette 2010: 379-91.

43 Johnson 1987, cf. Hampe 2005. The overall distinction made here has several things in common with the classical distinction proposed by Head and Holmes (1911-12), often cited as the pedigree of the influential notion of a 'body schema' (e.g. Gallagher 
1995). Head and Holmes distinguish between a postural schema, dealing with the state of the body as a whole, and a surface schema, dealing with stimulation of the surface of the skin.

44 Johnson (1987: 21-3).

45 Mentioned only briefly in the list of 'other basic schemata' in Johnson (1987: 126) (but for the usage under discussion here, cf. also Johnson's 'DISEASE AS LESION' model, ibid.: 134); cf. Peña (2008: 1044-6).

46 See Nyord (2009: 68-79).

47 Papyrus Hearst 14,10-13 (H 216) (= Grapow 1958: 536).

48 Presumably, based on the explicit mention in Papyrus Ebers 46,2 (Eb 238) (= Grapow 1958: 261 (as suggested by Westendorf 1999: 366)).

49 Papyrus Ebers 46,8-9 (Eb 241) (= Grapow 1958: 267).

50 Berlin Medical Papyrus 5,9-11 (Bln 58) (= Grapow 1958: 265).

51 Berlin Medical Papyrus 9,12-10,2 (Bln 116) (= Grapow 1958: 264).

52 London Medical Papyrus 10,1-10,2 (L 30) (= Grapow 1958: 482 ('L 42') - for the new numbering of recipes and lines in this manuscript, see Leitz (1999: 1 and 51).

53 Ostr. Cairo (= Grapow 1958: 102-3).

54 Berlin Medical Papyrus 8,1-2 (Bln 89) and 8,10-11 (Bln 101) (= Grapow 1958: 448 and 450-1).

55 Berlin Medical Papyrus 8,10 (Bln 101) (= Grapow 1958: 450).

56 Papyrus Louvre E 32847 vso 23,1 (= Bardinet 2018: 396).

57 Berlin Medical Papyrus 8,8-9 (Bln 99) (= Grapow 1958: 450).

58 Berlin Medical Papyrus 8,9 (Bln 99) (= Grapow 1958: 450).

59 Berlin Medical Papyrus 6,5 (Bln 65) (= Grapow 1958: 266-7), cf. Westendorf (1970: 146, 1999: 365 n. 555) for the reading.

60 See the overview of this class of objects in Dieleman (2015).

61 Papyrus Louvre E 32308, 1-8 (= Koenig 2004: 323).

62 E.g. Papyrus Turin 54050, verso, 4,2-5 (= Roccati 2011: 32): 'then (the enemy of) the sky shall split open; then (the enemy of) the earth shall turn itself over; then (3) Apep shall be victorious over the Bark of Millions; water shall not be given to the one who is in his sarcophagus; He who is in Abydos shall not be buried; He who is in Djedu shall not be hidden; (4) rites shall not be made for Him who is in Heliopolis; food-offerings shall not be made in their temples; the people shall not make food-offerings (5) at any of their festivals for any of the gods'.

63 As argued by Podemann Sørensen (1984).

64 See e.g. Nyord (2013) for the presence and mode of being of the dead in the tomb.

65 Often connected in turn to the notion of a post-mortem judgement and its positive or negative outcome with $m w t$-dead as 'damned', cf. e.g. Zandee (1960: 34-5); Janák (2013: 2-3).

66 A famous example being the reference in chapters 14 and 15 of the Daily Temple Ritual where the ritualist assures the god, 'I will not make your appearance resemble that of another god' (Ritual of Amun, Papyrus Berlin 3055, 5,4 and 5,6= Moret 1902: 59 and 62, cf. Guglielmi and Buroh 1997: 128-9), indicating the high level of malleability and the power of the ritualist to potentially influence the manifestation of the target of the ritual interaction.

67 Papyrus Edwin Smith 19,6-8 (= Breasted 1930: pl. 19).

68 Examples, which could be readily multiplied, include Mesopotamia (Geller 1985: 39; Scurlock 2006: 6), China (Poo 2009: 244-51) and twentieth-century America (Jones 1944: 244-5).

69 As also noted by Kousoulis (2007: 1045 n. 19).

70 Attestations of sick people lying in bed are remarkably rare in ancient Egypt, but cf. $C T$ II, 342a [157] (de Buck 1935-61: II, 342) = BD 112, 7 (Nu) (Lüscher 2012: 88/89d).

71 The single example of a remedy to be taken in the morning (Bln 116= Grapow 1958: 264-5) is part of a regiment where a basically similar set of ingredients are taken both morning and evening. 


\section{Rune Nyord}

72 Papyrus Edwin Smith 20,5-8 (= Breasted 1930: pl. 20).

73 Papyrus Turin 54050, verso, 2, 7 (= Roccati 2011: 30).

74 Papyrus Turin 54050, verso, 2, 11 (= Roccati 2011: 30).

75 Papyrus Turin 54050, verso, 3, 8 (= Roccati 2011: 31).

76 Papyrus Turin 54050, verso, 2, 8 (= Roccati 2011: 30).

77 Papyrus Turin 54050, verso, 2,8-3, 11 (= Roccati 2011: 30-1).

78 Papyrus Budapest 51.1961, 2,2-4 (= Kákosy 1981: 256).

79 Even in quite recent works, e.g. Westendorf (1999: 360). For the long-standing discussion about the traditional distinction between the 'medical' and the 'magical' in Egyptian healing practices, see Dieleman (2011: 92-3) and Nyord (forthcoming).

80 I am grateful to Ulrike Steinert for pointing out an interesting contrast with Mesopotamian conceptions in this regard, where gynaecological haemorrhages tend to be ascribed to witchcraft rather than ghosts.

81 London Medical Papyrus 9,3-7 (L 26) (= Grapow 1958: 268-9 ('L 38')). For this spell, see Leitz (2002: 137-9); Nyord (2008: 106-7, 2009: 457).

82 London Medical Papyrus 9,5 (L 26) (= Grapow 1958: 268-9 ('L 38')).

83 London Medical Papyrus 9,6-7 (L 26) (= Grapow 1958: 269 ('L 38')).

84 A parallel for comparison might be the 'wise woman' ( $t$ ' $r h t)$ in sources from New Kingdom Deir el-Medina, who is consulted, among other divinatory practices, to clarify the identity of the divine entity troubling a patient, cf. Borghouts (1982: 24-7); Toivari-Viitala (2001: 228-31).

85 London Medical Papyrus 9,5-6 (L 26) (= Grapow 1958: 269 ('L 38')).

86 See especially the recipe in the London Medical Papyrus 9, 9-14 (L 28) (= Grapow 1958: 482-3 (' $\mathrm{L} 40$ ')), where the risk of haemorrhage is connected with a $s t^{-}{ }^{c}(9,13)$, although its origin is not mentioned, as well as 'seeing a dream' $(9,14)$, and the spell in Papyrus Leiden I 348 against 'terrors which come to fall upon a man during the night' (verso 2,1 = Borghouts 1971: pl. 16), for which a broad list of categories of beings can be responsible, including 'a male or female dead' (verso 2,2 = Borghouts 1971: pl. 16). Cf. further the examples and discussion in Szpakowska (2003: 21-9). Ulrike Steinert has kindly pointed out to me the close parallels to the Mesopotamian concept of ha'attu (hay(y)attu) 'terror', cf. Oppenheim (1956: 1). See also Scurlock (2006) for seeing dead people in one's dreams as signs of illness and ghost-attack in Mesopotamian texts.

87 Papyrus Naga edDeir 3500, 3-4 (= Simpson 1970: pl. 46). Cf. Donnat Beauquier (2014: 51-3) for the letter.

88 Hu Bowl 4-6 (= Gardiner and Sethe 1928: pl. 4). Cf. Donnat Beauquier (2014: 44-8) for the letter.

89 Donnat Beauquier (2014, esp. 93-124).

90 Papyrus Naga edDeir N 3737, 2-3 (= Simpson 1966: pl. 9). Cf. Donnat Beauquier (2014: 48-51) for the letter.

91 See Westendorf 1999: 421-5.

92 See the recent treatments of the need for protection at childbirth and the associated objects and iconography in Wegner (2009); Quirke (2016).

93 Papyrus Ramesseum IV, fragment C, 17 (= Grapow 1958: $500=$ Barns 1956: pl. 18).

94 Papyrus Ramesseum IV, fragment C, 20-21 (= Barns 1956: pl. 18).

95 Papyrus Berlin 3027, verso 3,1; 3,5; 4,1; 4,4 (= Yamazaki 2003: pls. 4-5).

96 Papyrus Berlin 3027, verso 3,5-6; 4,2; 4,5 (= Yamazaki 2003: pls. 4-5). In the same collection, the dead are also seen as responsible for causing problems with the mother's lactation (Spell O, verso 1,2-4 = Yamazaki 2003: pl. 2) as well as pain and fever in the child (Spell N, recto 9,5-6 = Yamazaki 2003: pl. 10).

\section{References}

Baines, J. and Lacovara, P. (2002) 'Burial and the Dead in Ancient Egyptian Society: Respect, Formalism, Neglect', Journal of Social Archaeology 2, 5-36. 
Bardinet, T. (1995) Les papyrus médicaux de l'Égypte pharaonique. Paris: Fayard.

Bardinet, T. (2018) Médecins et magiciens à la cour du pharaon: Une étude du Papyrus Médical Louvre E 32847. Paris: Éditions Khéops.

Barns, J. W. B. (1956) Five Ramesseum Papyri. Oxford: Griffith Institute.

Borghouts, J. F. (1971) The Magical Texts of Papyrus Leiden I 348. Leiden: Brill.

Borghouts, J. F. (1982) 'Divine Intervention in Ancient Egypt and Its Manifestation (b3w)', in Demarée, R. J. and Janssen, J. J. (eds.) Gleanings from Deir el-Medîna. Leiden: Nederlands Instituut voor het Nabije Oosten, 1-70.

Boyer, P. (1990) Tradition as Truth and Communication: A Cognitive Description of Traditional Discourse. Cambridge: Cambridge University Press.

Breasted, J. H. (1930) The Edwin Smith Surgical Papyrus. Chicago: University of Chicago Press.

De Buck, A. (1935-61) The Egyptian Coffin Texts. Vols. 1-7. Chicago: Oriental Institute.

De Buck, A. (1939) De godsdienstige opvatting van den slaap in zonderheid in het oude Egypte. Leiden: Brill.

Dieleman, J. (2011) 'Scribal Practices in the Production of Magic Handbooks in Egypt', in Bohak, G., Harari, Y. and Shaked, S. (eds.) Continuity and Innovation in the Magical Tradition. Leiden: Brill, 85-117.

Dieleman, J. (2015) 'The Materiality of Textual Amulets in Ancient Egypt', in Boschung, D. and Bremmer, J. N. (eds.) The Materiality of Magic. Paderborn: Wilhelm Fink, 23-58.

Donnat, S. (2007) 'Contacts with the Dead in Pharaonic Egypt: Ritual Relationships and Dead Classification'. Unpublished manuscript (http://rennesegypto.free.fr/IMG/pdf/ Sylvie_Donnat.pdf) (Accessed 18 August 2017).

Donnat, S. and Moreno Garcia, J. C. (2014) 'Integration du mort dans la vie sociale égyptienne à la fin du troisième millénaire av. J.-C.', in Mouton, A. and Patrier, J. (eds.) Life, Death, and Coming of Age in Antiquity: Individual Rites of Passage in the Ancient Near East and Adjacent Regions. Leiden: Nederlands Instituut voor het Nabije Oosten, 179-207.

Donnat Beauquier, S. (2014) Écrire à ses morts: Enquête sur un usage rituel de l'écrit dans l'Égypte pharaonique. Grenoble: Jérôme Millon.

Foster, G. M. (1976) 'Disease Etiologies in Non-Western Medical Systems', American Anthropologist 78, 773-82.

Frandsen, P. J. (2001) 'Bwt in the Body', in Willems, H. (ed.) Social Aspects of Funerary Culture in the Egyptian Old and Middle Kingdoms. Leuven/Paris/Sterling: Peeters, 141-74.

Gallagher, S. (1995) 'Body Schema and Intentionality', in Bermudez, J. L., Marcel, A. and Eilan, N. (eds.) The Body and the Self. Cambridge, MA/London: MIT Press, 225-44.

Gamer-Wallert, I. (1970) Fische und Fischkulte im alten Ägypten. Wiesbaden: Harrassowitz. Gardiner, A. H. (1953) The Ramesseum Papyri. Oxford: Griffith Institute.

Gardiner, A. H. and Sethe, K. (1928) Egyptian Letters to the Dead Mainly from the Old and Middle Kingdoms. London: Egypt Exploration Society.

Geisen, C. (2018) A Commemoration Ritual for Senwosret I: P. BM EA 10610.1-5/P: Ramesseum B (Ramesseum Dramatic Papyrus). New Haven: Yale Egyptological Institute.

Geller, M. (1985) Forerunners to Udug-hul: Sumerian Exorcistic Incantations. Wiesbaden: F. Steiner.

Germer, R. (1986) 'Weihrauch', in Helck, W. and Westendorf, W. (eds.) Lexikon der Ägyptologie. Vol. 6. Wiesbaden: Harrassowitz, 1167-9.

Glucklich, A. (1994) The Sense of Adharma. New York/Oxford: Oxford University Press.

Grapow, H. (1958) Die medizinischen Texte in hieroglyphischer Umschreibung autographiert. Berlin: Akademie-Verlag. 


\section{Rune Nyord}

Guglielmi, W. and Buroh, K. (1997) 'Die Eingangssprüche des Täglichen Tempelrituals nach Papyrus Berlin 3055 (I, 1-VI, 3)', in van Dijk, J. (ed.) Essays on Ancient Egypt in Honour of Herman te Velde. Groningen: Styx, 101-66.

Hampe, B. (2005) From Perception to Meaning: Image Schemas in Cognitive Linguistics. Berlin/New York: Mouton de Gruyter.

Head, H. and Holmes, G. (1911-12) 'Sensory Disturbances from Cerebral Lesions', Brain $34,102-254$.

Janák, J. (2013) 'Akh', in Dieleman, J. and Wendrich, W. (eds.) UCLA Encyclopedia of Egyptology. Los Angeles: eScholarship (http://digital2.library.ucla.edu/viewItem.do?ark= 21198/zz002gc1pn) (Accessed 8 November 2017).

Jean, R.-A. and Loyrette, A.-M. (2010) La mère, l'enfant et le lait en Égypte ancienne. Paris: L'Harmattan.

Johnson, M. (1987) The Body in the Mind: The Bodily Basis of Meaning, Imagination, and Reason. Chicago: University of Chicago Press.

Jones, L. C. (1944) 'The Ghosts of New York: An Analytical Study', Journal of American Folklore 226, 237-54.

Kákosy, L. (1981) Selected Papers (1956-73). Budapest: ELTE.

Koenig, Y. (2004) 'Le papyrus de Moutemheb', Bulletin de l'Institut Français d'Archéologie Orientale 104, 291-326.

Kousoulis, P. (2007) 'Dead Entities in Living Bodies: The Demonic Influence of the Dead in the Medical Texts', in Goyon, J. C. and Gardin, C. (eds.) Proceedings of the Ninth International Congress of Egyptologists. Leuven: Peeters, 1043-50.

Leitz, C. (1999) Magical and Medical Papyri of the New Kingdom. London: British Museum Press.

Leitz, C. (2002) 'Zwischen Zauber und Vernunft: Der Beginn des Lebens im Alten Ägypten', in Karenberg, A. and Leitz, C. (eds.) Heilkunde und Hochkultur I: Geburt, Seuche und Traumdeutung in den antiken Zivilisationen des Mittelmeerraumes. Münster/Hamburg/ London: LIT, 133-50.

Lock, M. (2001) 'The Tempering of Medical Anthropology: Troubling Natural Categories', Medical Anthropology Quarterly 15(4), 478-92.

Lüscher, B. (2012) Die Sprüche vom Kennen der Seelen (Tb 107-109, 111-116). Basel: Orientverlag.

Manniche, L. (2009) 'Perfume', in Wendrich, W. (ed.) UCLA Encyclopedia of Egyptology. Los Angeles: eScholarship (http://escholarship.org/uc/item/0pb1r0w3) (Accessed 8 November 2017).

Moret, A. (1902) Le rituel du culte divin journalier en Égypte d'après le papyrus de Berlin et les textes du temple de Séti Ier, à Abydos. Paris: Ernest Leroux.

Morschauser, S. (1991) Threat-Formulae in Ancient Egypt. Baltimore: Halgo.

Nordh, K. (1996) Aspects of Ancient Egyptian Curses and Blessings: Conceptual Background and Transmission. Uppsala: Uppsala University.

Nyord, R. (2008) 'Forfædre, frugtbarhed og genfærd: Nogle tanker om livet og døden fra det gamle Ægypten', in Friborg, F. and Jørgensen, M. (eds.) Tidernes morgen. På sporet af kulturens kilder $i$ det gamle Mellemøsten. Copenhagen: Ny Carlsberg Glyptotek, 98-108.

Nyord, R. (2009) Breathing Flesh: Conceptions of the Body in the Ancient Egyptian Coffin Texts. Copenhagen: Museum Tusculanum.

Nyord, R. (2013) 'Memory and Succession in the City of the Dead: Temporality in the Ancient Egyptian Mortuary Cult', in Willerslev, R. and Christensen, D. (eds.) Taming Time, Timing Death: Social Technologies and Ritual. Farnham: Ashgate, 195-211. 
Nyord, R. (2017) 'Analogy and Metaphor in Ancient Medicine and the Ancient Egyptian Conceptualisation of Heat in the Body', in Wee, J. Z. (ed.) The Comparable Body: Analogy and Metaphor in Ancient Mesopotamian, Egyptian, and Greco-Roman Medicine. Leiden: Brill, 12-42.

Nyord, R. (2019) 'Introduction: Egyptian and Egyptological Concepts', in Nyord, R. (ed.) Concepts in Middle Kingdom Funerary Culture: Proceedings of the Lady Wallis Budge Anniversary Symposium Held at Christ's College, Cambridge, 22 January 2016. Leiden: Brill, 1-23.

Nyord, R. (forthcoming) 'Texts for Healing and Protection', in Shaw, I. and Bloxam, E. (eds.) Oxford Handbook of Egyptology. Oxford: Oxford University Press, 1039-52.

Oppenheim, L. (ed.) (1956) The Assyrian Dictionary of the Oriental Institute of the University of Chicago, Volume 6: H. Chicago/Glückstadt: Oriental Institute/J. J. Augustin.

Otto, B.-C. (2013) 'Zauberhaftes Ägypten - Ägyptischer Zauber: Überlegungen zur Verwendung des Magiebegriffs in der Ägyptologie', in Jeserich, F. (ed.) Ägypten - Kindheit - Tod: Gedenkschrift für Edmund Hermsen. Vienna/Cologne/Weimar: Böhlau, 39-70.

Peña, M. S. (2008) 'Dependency Systems for Image-Schematic Patterns in a Usage-Based Approach to Language', Journal of Pragmatics 40, 1041-66.

Petrie, W. M. F. (1900) Dendereh 1898. London: Egypt Exploration Fund.

Podemann Sørensen, J. (1984) 'The Argument in Ancient Egyptian Magical Formulae', Acta Orientalia 45, 5-19.

Poo, M.-C. (2009) 'The Culture of Ghosts in the Six Dynasties Period (c. 220-589 C.E.)', in Poo, M.-C. (ed.) Rethinking Ghosts in World Religions. Leiden/Boston: Brill, 237-67.

Quirke, S. (2016) Birth Tusks: The Armoury of Health in Context: Egypt 1800 BC. London: Golden House.

Reiner, E. and Roth, M. T. (eds.) (1999) The Assyrian Dictionary of the Oriental Institute of the University of Chicago, Volume 14: R. Chicago: Oriental Institute.

Roccati, A. (2011) Magia Taurinensia: Il grande papiro magico di Torino e i suo duplicate. Rome: Gregorian and Biblical Press.

Scurlock, J. (2006) Magico-Medical Means of Treating Ghost-Induced Illnesses in Ancient Mesopotamia. Leiden/Boston: Brill.

Sethe, K. (1908-22) Die altaegyptischen Pyramidentexte. Leipzig: Hinrichs.

Sethe, K. (1928) Dramatische Texte zu altägyptischen Mysterienspielen, II: Der dramatische Ramesseum-papyrus - Ein Spiel zur Thronbesteigung des Königs. Leipzig: J. C. Hinrichs.

Simpson, W. K. (1966) 'The Letter to the Dead from the Tomb of Meru (N 3737) at Nag' ed-Deir', Journal of Egyptian Archaeology 52, 39-52.

Simpson, W. K. (1970) 'A Late Old Kingdom Letter to the Dead from Nag' ed-Deir N 3500', Journal of Egyptian Archaeology 56, 58-64.

Szpakowska, K. (2003) Behind Closed Eyes: Dreams and Nightmares in Ancient Egypt. Swansea: Classical Press of Wales.

Szpakowska, K. (2011) 'Demons in the Dark: Nightmares and other Nocturnal Enemies in Ancient Egypt', in Kousoulis, P. (ed.) Ancient Egyptian Demonology: Studies on the Boundaries between the Demonic and the Divine in Egyptian Magic. Leuven: Peeters, 63-76.

Toivari-Viitala, J. (2001) Women at Deir el-Medina: A Study of the Status and Roles of the Female Inhabitants in the Workmen's Community during the Ramesside Period. Leiden: Nederlands Instituut voor het Nabije Oosten.

Topmann, D. (2002) Die 'Abscheu'-Sprüche der altägyptischen Sargtexte: Untersuchungen zu Textemen und Dialogstrukturen. Wiesbaden: Harrassowitz. 


\section{Rune Nyord}

Viveiros de Castro, E. (1998) 'Cosmological Deixis and Amerindian Perspectivism', Journal of the Royal Anthropological Institute, 4(3), 469-88.

Von Deines, H. and Westendorf, W. (1962) Wörterbuch der Medizinischen Texte, zweite Hälfte $(h-\underline{d})$. Berlin: Akademie-Verlag.

Wegner, J. (2009) 'A Decorated Birth-Brick from South Abydos: New Evidence on Childbirth and Birth Magic in the Middle Kingdom', in Silverman, D. P., Simpson, W. K. and Wegner, J. (eds.) Archaism and Innovation: Studies in the Culture of Middle Kingdom Egypt. New Haven/Philadelphia: Department of Near Eastern Languages and Civilizations, Yale University and University of Pennsylvania Museum of Archaeology and Anthropology, 447-96.

Westendorf, W. (1970) 'Beiträge aus und zu den medizinischen Texten', Zeitschrift für Ägyptische Sprache und Altertumskunde 96, 145-51.

Westendorf, W. (1999) Handbuch der altägyptischen Medizin. Leiden/Boston/Cologne: Brill.

Yamazaki, N. (2003) Zaubersprüche für Mutter und Kind: Papyrus Berlin 3027. Berlin: Achet.

Zandee, J. (1960) Death as an Enemy According to Ancient Egyptian Conceptions. Leiden: Brill. 